\title{
Reduction of Embodied Energy and Construction Cost of Affordable Houses through Efficient Architectural Design: A Case Study in Indian Scenario
}

\author{
Deepak Bansal (iD, ${ }^{1}$ V. K. Minocha, ${ }^{2}$ Arvinder Kaur, ${ }^{3}$ Vaidehi A. Dakwale, ${ }^{4}$ \\ and R. V. Ralegaonkar ${ }^{4}$ \\ ${ }^{1}$ GGSIP University Delhi 110075, India \& Joint General Manager with Housing and Urban Development \\ Corporation Limited (HUDCO), New Delhi 110003, India \\ ${ }^{2}$ Delhi Technological University, New Delhi 110042, India \\ ${ }^{3}$ GGSIP University, New Delhi 110075, India \\ ${ }^{4}$ Civil Engineering Department, VNIT, Nagpur 440010, Maharashtra, India
}

Correspondence should be addressed to Deepak Bansal; dbansalindia@gmail.com

Received 9 July 2021; Revised 20 August 2021; Accepted 31 August 2021; Published 9 September 2021

Academic Editor: Amos Darko

Copyright $\odot 2021$ Deepak Bansal et al. This is an open access article distributed under the Creative Commons Attribution License, which permits unrestricted use, distribution, and reproduction in any medium, provided the original work is properly cited.

\begin{abstract}
Embodied energy and cost of construction of any building depends upon the consumption of resources, more specifically construction materials. In housing clusters, the spaces provided for horizontal and vertical circulation of occupants such as corridors and contribute in the built-up area of individual unit without any increase in the usable/carpet area. Thus, an efficient architectural planning of common circulation spaces plays a major role in lowering the built-up-to-carpet area ratio of individual housing unit in clusters. This may, thus, result in lesser embodied energy and maximum area availability for occupant usage. In the present study, 30 clusters of Indian affordable housing units (IAHUs) of similar typology and different architectural designs are analyzed. The built-up and carpet area of each IAHU are estimated, and the ratio of the built-up to carpet area is calculated. Detailed estimates of construction materials for each IAHU is prepared, and cost of construction and embodied energy is calculated. The calculations of embodied energy and construction cost are done for major construction materials, viz., cement, steel, bricks, sand, and coarse aggregate and compared with different built-up-to-carpet area ratio. The study of IAHUs concludes that a variation of 1.30 to 1.62 in the built-up area-to-carpet area ratio results in variation in construction cost (INR 13,425.00 to 20,138.00 per $\mathrm{m}^{2}$ carpet area) and embodied energy (4-6.5 GJ per $\mathrm{m}^{2}$ carpet area). Analysis suggests that the IAHU with a lower built-up-to-carpet area ratio exhibits reduction in the cost of construction and embodied energy simultaneously. Thus, an efficient architectural design plays a major role in improving the sustainability of IAHUs and built-up-to-carpet area ratio is an important indicator of sustainability.
\end{abstract}

\section{Introduction}

Life cycle energy of buildings is associated with different phases of buildings, which includes embodied energy (EE), operating energy (OE), and energy required for demolition and disposal. Of these, major phases of energy consumption are construction or preoccupancy phase (EE) and operational or occupancy phase (OE) [1-10]. EE of the buildings is the sum of all energy incurred on sourcing, procession/ manufacturing of building materials, and transportation of building materials including construction equipment and labor, energy incurred for onsite construction, and all secondary and tertiary process. Life cycle energy of buildings due to demolition, disposal, and transportation of material and use of construction equipment is very less, that is, $1-2 \%$ [11-14] and $0.7 \%$ [15-17], respectively. The energy in construction activities is negligible due to the predominance of manual labor in Asia $[12,13,16,18]$. 
Furthermore, the energy usage pattern in buildings depends on many factors. Low-rise and high-rise buildings, load bearing, RCC framed structures or hybrid construction, building use, buildings with different construction materials/envelopes/typologies, and so on, have different patterns of energy consumption during its lifetime $[16,19,20]$. In conventional buildings, $\mathrm{OE}$ is more predominant, whereas in energy efficient buildings, EE becomes significant $[2,15,21-29]$. There are two approaches for reduction of EE of any building: first, using low embodied energy construction material and second, by material resource conservation. The material resource load can be expressed as quantity of material used per unit of area. In housing clusters, the built-up area of an individual house is the addition of its own carpet area, external wall area in plan, and proportionate built-up area derived from common spaces and utilities. The utilities may be lifts, staircases, corridors, and so on. The houses intended for economically weaker sections (EWSs) have a low built-up area, and thus, material resource conservation becomes crucial for reducing its EE. Construction materials, which have high embodied energy and high cost, are used minimally in housing for economically weaker sections [3, 7, 12, 28, 29], further reducing its embodied energy (EE), life cycle energy (LCE), and construction cost (CC).

In India, Pradhan Mantri Awas Yojna (PMAY) [30] is an ambitious social housing scheme carried out by Government of India and is being implemented by its Ministry of Housing and Urban Affairs (MoHUA) for providing affordable housing with basic amenities to the masses on panIndia basis. This mission addresses housing shortages among the economically weaker sections (EWS) including slum dwellers by ensuring a permanent house to all eligible households. The mission supports construction of houses of about $30-60 \mathrm{~m}^{2}$ carpet area with basic civic infrastructure for the EWS population.

The requirement of $\mathrm{OE}$ in IAHUs is limited due to the inability to afford heating and cooling systems due to financial issues of the stakeholders. In this scenario, EE becomes more significant for improving sustainability index of the Indian affordable housing $[3,7,9,12,30,31]$. Life cycle energy (LCE) of a building is expressed as energy consumed per unit area. In this expression, the denominator may be either the built-up area or carpet area. Therefore, any building may have two boundary values of LCE: higher limiting value with carpet area and lower limiting value with built-up area, unless the built-up and carpet areas are equal. Since the carpet area is the actual usable area available to occupants, the LCE value with the carpet area in the denominator becomes significant. Thus, the LCE values reported with the built-up area in the denominator may give a false interpretation of lower embodied energy or LCE of the buildings. In other words, the ratio of the built-up to carpet area is a major indicator in expressing the embodied energy and cost indexes in sustainable buildings. This indicator becomes even crucial in buildings, where energy efficiency is defined by primarily construction material conservation, such as housing for EWS. Efficient architectural design and judicious planning of common circulation areas and other spaces in buildings help to reduce requirement of construction materials, thus reducing EE and CC. The present paper investigates the effect of the built-up-to-carpet area ratio on EE and $\mathrm{CC}$ by analyzing 30 case studies of housing for the EWS in the Indian scenario.

\section{Literature Review}

In literature, life cycle energy analysis (LCEA) for different types of buildings has been carried out and values of LCE, $\mathrm{EE}, \mathrm{OE}$, and $\mathrm{CC}$ are reported for per unit area of the buildings [2-9, 16, 19, 20, 32-37]. The prescribed LCA/ LCEA values in the literature may vary too much due to different system boundaries and typologies of the buildings, and thus, it is reflected in the energy footprint per $\mathrm{m}^{2}$ of area $[8,13,23,26,37]$. The type of structures (framed/load bearing/hybrid) [28], height [29], occupancy type (Apartment/individual/population), circulation spaces, built-up area [38], etc., have different requirement of construction materials. Reducing wall thickness and designing circulation spaces efficiently will not only increase the carpet area of the building but also reduce demand of construction materials, which, in turn, reduces CC and EE of the buildings. It has been observed in literature that while reporting LCE values, the ratio of the built-up area and carpet area varies from 1 to 1.45 .

Pacheco-Torres et al. [39] analyzed a three-storey house in Spain with a built-up area of $313.13 \mathrm{~m}^{2}$ and total carpet area as $260.86 \mathrm{~m}^{2}$. The results were reported on an energy per unit area basis taking the built-up area in the denominator. Paulsen and Sposto [4] analyzed houses with mass in Brazil for an area of $48 \mathrm{~m}^{2}$; however, as per available drawings, the carpet area is $43.40 \mathrm{~m}^{2}$. This is 1.10 times higher than the carpet area. Das [32] have analyzed housing complexes in India for energy conservation, with apartments of different built-up areas. However, the author assumed that the same set of staircases and lifts can be fitted into any design, which may not be correct. Pinky Devi and Palaniappan [3] have analyzed an affordable, single-storey house in India with an area of $32.5 \mathrm{~m}^{2}$, but as per architectural drawings, the carpet area is $22.32 \mathrm{~m}^{2}$, resulting in a ratio of 1.45 . Oyarzo and Peuportier [33] have analyzed houses in Chile, with an area of $32 \mathrm{~m}^{2}$, a carpet area of $32 \mathrm{~m}^{2}$ as per drawings, and the ratio as 1 . Embodied energy values of low-rise Indian affordable housing have been compiled by Bansal et al., [20] as $1.6-5.0 \mathrm{GJ} / \mathrm{sqm}$ of plinth area.

EE can also be reduced using alternative construction materials and physical planning. Bansal et al. [7] \& Stephan and Athanassiadis, [40]. Antonín et al. [41] have studied strategies for reducing embodied energy and $\mathrm{CO}_{2}$ emission through efficient designing building elements, structural system, and passive systems of houses. Vukotic et al., [42] have presented ways for optimization of energy in different stages of building, primarily by construction materials. Worth et al. [43] have optimized a roofing system based on $\mathrm{EE}$ and cost.

From the literature, it has been observed that as the height of buildings increases, the circulation space requirement increases, thus increasing the built-up-to-carpet 
area ratio. Bansal et al., [44] carried out a study to find the variation in the carpet area and built-up area for different heights of buildings from single storied to 30 storied and found that for the same carpet area, built-up areas increased from $32 \%$ to $148 \%$ as the height of the building increases $[20,44]$. The results are presented in Figures 1(a) and 1(b) below. The increase is visualized due to the increase in provision of floor area for circulation spaces for staircases, lifts, elevator, and so on in high-rise buildings.

However, in the studied literature, the discussion on change in LCE, EE, and CC values due to difference in the built-up-to-carpet area ratio is not highlighted. Thus, an integrated approach toward reducing EE and CC of a building design efficiency in terms of the built-up area-tocarpet area ratio is not addressed in past studies. In the present study, authors investigate the effect of the built-upto-carpet area ratio on EE and CC of buildings specifically for EWS housing projects. Thirty buildings from Indian affordable housing units (IAHU) are identified and analyzed. Buildings are analyzed for their architectural designbased design efficiency in terms of the built-up area-tocarpet area ratio. EE and CCs have been calculated per $\mathrm{m}^{2}$ of built-up and carpet areas to choose the optimum architectural design with the least EE and CC. This will provide an integrated approach to designers about the design efficiency of architectural designs, in terms of EE and CC, based on the ratio of the built-up to carpet area. The design efficiency of architectural design will help in analyzing sustainable buildings by the finding optimum range of ratio of builtup-carpet area that will result in minimum construction cost and embodied energy.

\section{Methodology}

In the present study, 30 representative Indian affordable housing units (IAHU) from PMAY have been selected for this case study. These buildings have been designed according to the guidelines of PMAY and the technical specifications of National Building Code of India (NBC) [45] and are located in different parts of country. These 30 IAHUs have ground plus two storeys with a load-bearing structure. Each IHAU is designed as cluster consisting of 2 to 12 apartments per storey. The service life of buildings in India is about 50 years $[28,31]$. The plan for a typical IAHU is presented in Figure 2. Table 1 presents specifications of IAHU. While designing the IAHU, the safe bearing capacity of soil is taken as $11 \mathrm{MT} / \mathrm{m}^{2}$ at 1.0 metre depth from natural ground level, seismic zone III, and basic wind speed $47 \mathrm{~m} / \mathrm{s}$ as per the NBC.

The architectural plan in terms of length of walls, openings, arrangement of rooms, and provision of common spaces in a cluster play a major role in building construction. For the same built-up area, if the number of internal walls or the area of staircases, corridors, and so on increases, the effective or usable area (carpet area) will reduce and vice versa. This change is reflected in the consumption of construction materials or bills of quantity as well. The quantity of construction material thus varies per unit of the built-up/ carpet area in different architectural designs due to the different arrangement of walls and spaces. Since reinforcing steel, cement, fired clay bricks, sand, and coarse aggregates are the main contributors in construction cost (CC) and embodied energy (EE) [46-48]; any change in the quantities of these construction materials is reflected positively or negatively in CC and EE. Thus, an efficient design may lead to reduction in CC and EE, and the built-up area-to-carpet area ratio plays a significant role in the overall CC and EE of buildings. Figure 3 indicates the interrelation of these parameters.

The present study investigates and quantifies effect of the built-up area-to-carpet area ratio on $\mathrm{CC}$ and $\mathrm{EE}$ of 30 case study IAHUs. The IAHUs are designated as A1 to A30 and arranged in the ascending order of the built-up area in Table 2, which presents the built-up area and carpet area values of the selected IAHU. As evident, the built-up area-tocarpet area ratio changes from 1.30 to 1.62 due to the change in architectural design.

The bill of quantities for the IAHU in this study has been prepared. Since cost estimates prepared by government agencies are based on the schedule of rates published by the Central Public Works Department (CPWD) and Delhi scheduled Rates (DSRs) 2016 [49], the cost of construction materials is adopted from these publications and presented in Table 3.

Similarly, the EE value for 30 IAHUs based on major construction material consumption was calculated. Since the embodied energy of a material depends on a variety of factors such as raw material (local/imported), processing (manual/mechanical), transportation, and so on [50-52], the embodied energy values have been taken from the Indian scenario $[9,50,52,53]$ as well as international sources [54]. These values are presented and compared in Table 4. These values show large variations, which is primarily due to the factors discussed earlier. To represent the local condition, in this study, the EE values from the Indian scenario are considered for the calculation of EE of the case study IAHU.

\section{Results and Discussion}

Construction materials are major contributors to $\mathrm{CC}$ and $\mathrm{EE}$ in any building construction. In the present study, the bill of quantity for each IAHU is tabulated and the cost of construction is calculated based on consumption of construction materials. Cost of construction includes materials, labor, electrical, plumbing, and so on completely. As per the CPWD 2016 [55], the cost of construction materials is about $36 \%$, cost of labor is $30 \%$, PHE/electrical works is $7 \%$, hire charges of tool and plants, consumables and miscellaneous is $12 \%$, and contractor profit is taken as $15 \%$, making a total of $100 \%$. Table 5 presents a summary of cost of construction for 30 IAHUs and indicates that the cost of construction varies between INR 13,425.00 to $20,138.00$ per $\mathrm{m}^{2}$ of carpet area. It is seen from Table 4 that the built-up area varies from 1.30 to 1.62 of carpet area due to different architectural designs with the same specifications and the same functional requirements. This is reflected in the construction cost of the IAHU.

The total cost of major construction materials such as fired clay bricks, cement, steel, sand, and aggregates is 


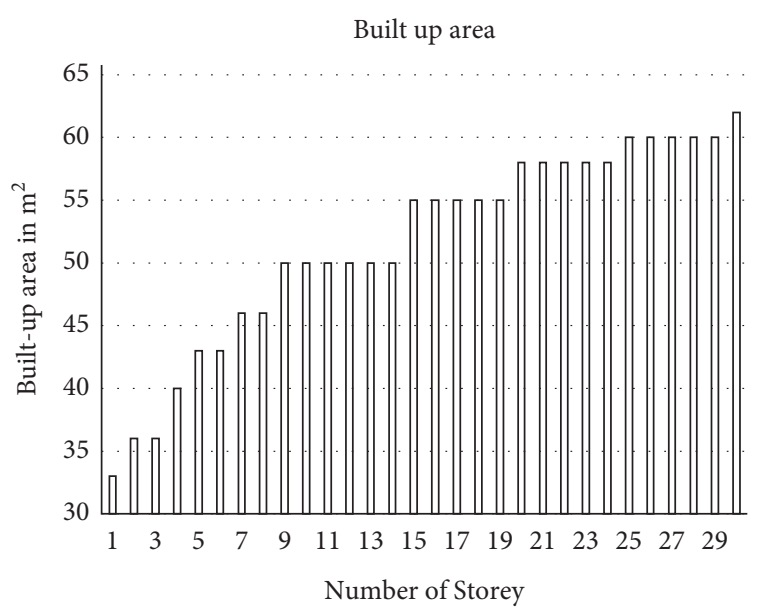

(a)

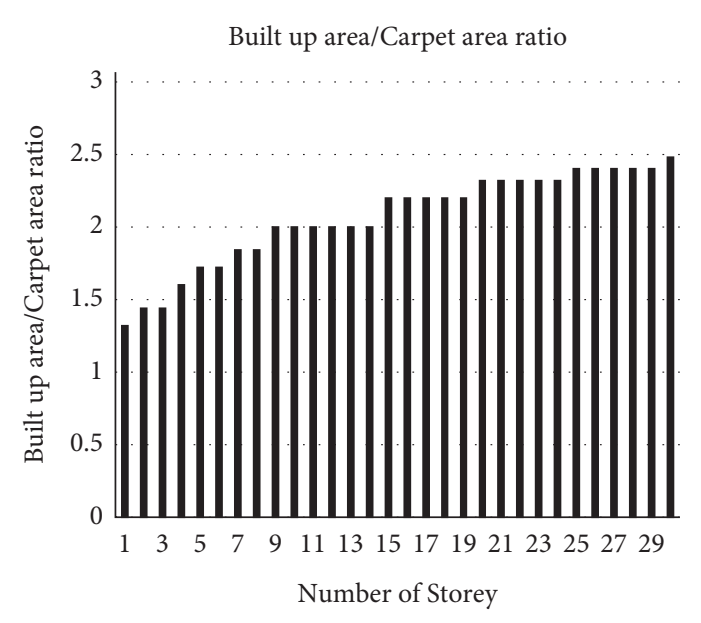

(b)

FIGURE 1: Table showing relation between number of storey and built up area, carpet area.

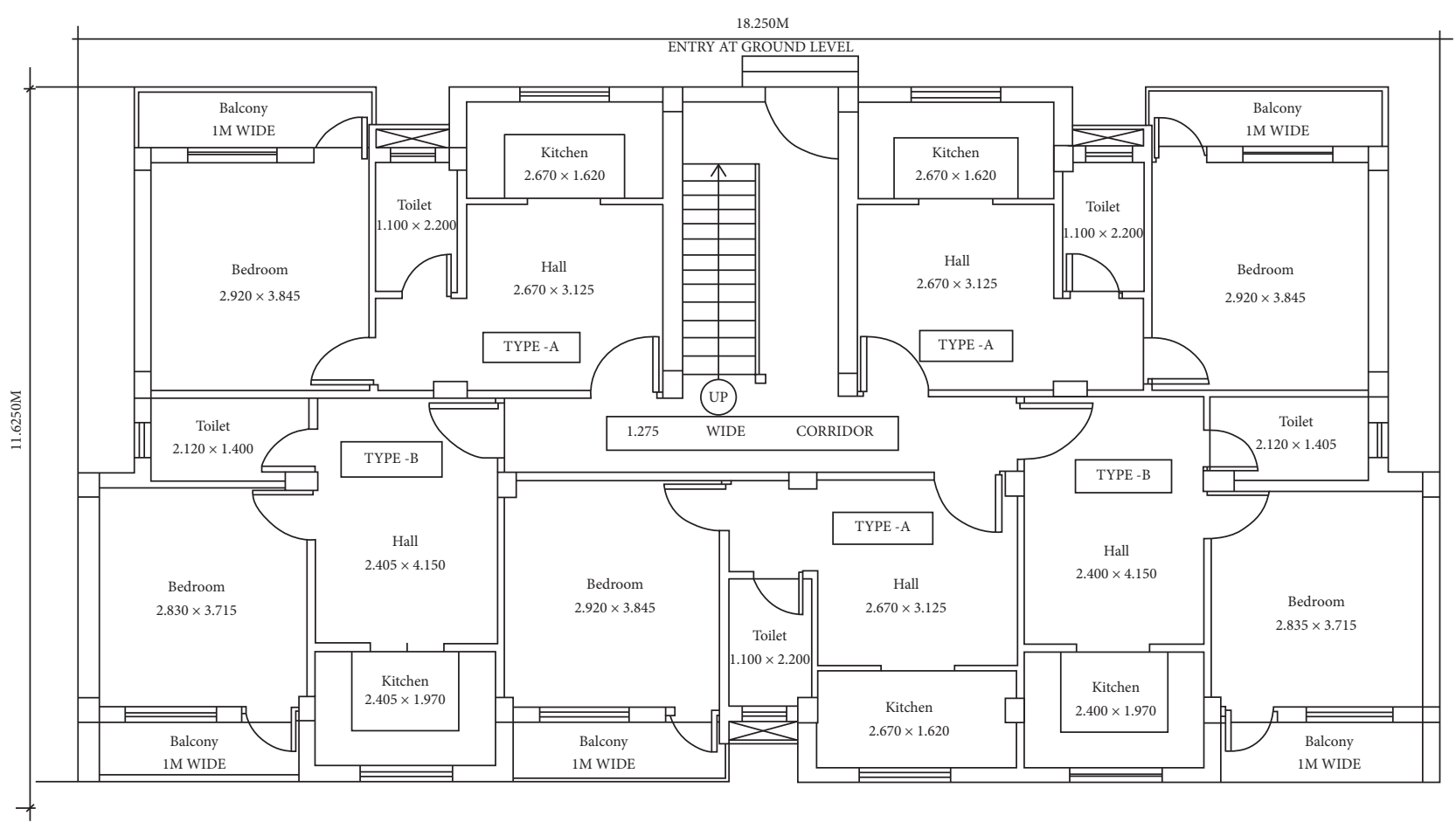

FIgURE 2: Typical architectural design of an IAHU [30].

calculated from the bill of quantities for each IAHU and is tabulated in Table 6 with the per unit carpet area. It is also observed that cement, sand, aggregate, steel, and brick together account for $35 \%-38 \%$ of the total cost of construction that varies from INR $4,697.00$ to $7,433.00$ per $\mathrm{m}^{2}$ on the carpet area basis with brick as the major contributor. It is evident from Table 6 that in the load-bearing structure, brick, cement, and steel contribution is in the descending order of the total cost of building. Thus, reducing consumption of these construction materials reduces the overall cost of construction.
Similarly, EE of major construction materials has been calculated and presented in Table 7. For calculation of embodied energy, the average values of EE indicated in Table 4, for respective construction materials has been used. It is observed that fired clay bricks are major contributors in the total EE of IAHUs. Thus, a good architectural design with lesser volume of main and interior walls plays a major role in reducing $\mathrm{EE}$ of the IAHU.

From the results, it is observed that the minimum cost of construction and EE is corresponding to built-up-to-carpet area ratio 1.31 for IAHU, which is design no. A22 and the 
TABLE 1: Specifications of the chosen Indian affordable housing [44].

\begin{tabular}{|c|c|c|}
\hline $\begin{array}{l}\text { S. } \\
\text { no. }\end{array}$ & Component & Details \\
\hline 1 & Structure & Load-bearing structure \\
\hline 2 & Wall & $230 \mathrm{~mm}$ thick brick masonry in mortar with cement and coarse sand in 16 proportion \\
\hline 3 & Roof & $\begin{array}{l}115 \mathrm{~mm} \text { thick flat reinforced cement concrete (RCC) roof with concrete of M25 grade and with TMT Fe } \\
\text { 500D grade reinforcement, } 1 \% \text { by volume of RCC }\end{array}$ \\
\hline 4 & Flooring & $40 \mathrm{~mm}$ thick plain cement concrete (PCC) of M15 grade \\
\hline 5 & Skirting/dado & $12 \mathrm{~mm}$ thick $100 \mathrm{~mm} / 1200 \mathrm{~mm}$ high, in mortar with cement and coarse sand in 16 proportion \\
\hline 6 & Plaster/rendering & $12 / 15 \mathrm{~mm}$ thick with in mortar with cement and coarse sand in 16 proportion \\
\hline 7 & Terrace finishing & $\begin{array}{l}100 \mathrm{~mm} \text { average with brick tiles and mud fuska (treatment with local clay and mud to reduce radiant heat } \\
\text { gain) }\end{array}$ \\
\hline 8 & Parapet & $900 \mathrm{~mm}$ high in $115 \mathrm{~mm}$ thick brick masonry in mortar with cement and coarse sand in 14 proportion \\
\hline 9 & Joinery & Mild steel frames with steel grills and glass panels \\
\hline 10 & $\begin{array}{l}\text { CC gola/khurrah/ } \\
\text { coping }\end{array}$ & $\begin{array}{c}\text { CC gola (over the deck treatment at junction of parapet wall and roof slab to prevent seepage) in PCC of M15 } \\
\text { grade } \\
\text { Khurrah (rainwater spout) } \\
\text { Coping (PCC over parapets to protect it from rainwater) }\end{array}$ \\
\hline
\end{tabular}

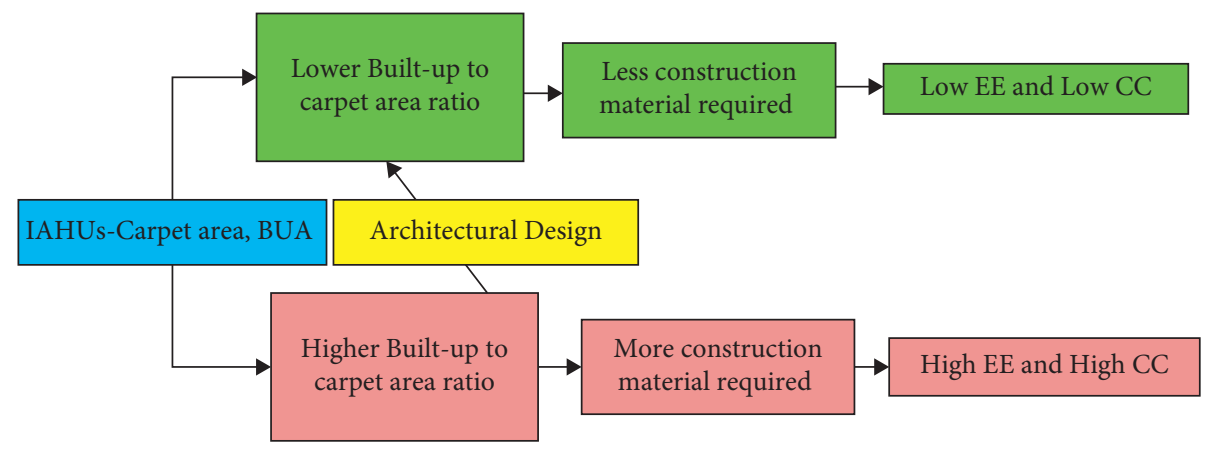

FIGURE 3: Interrelation of the construction area, built-up area-to-carpet area ratio, construction cost, and embodied energy.

TABle 2: Carpet area, built-up area, and built-up-to-carpet area ratio for selected 30 IAHUs.

\begin{tabular}{lcccc}
\hline IAHU & Built-up area $\left(\mathrm{m}^{2}\right)$ & Area occupied by common amenities and external walls & Carpet area $\left(\mathrm{m}^{2}\right)$ & Built-up area-to-carpet area ratio \\
\hline A1 & 28.47 & 8.45 & 20.02 & 1.42 \\
A2 & 30.50 & 9.71 & 20.79 & 1.47 \\
A3 & 30.81 & 7.78 & 23.03 & 1.34 \\
A4 & 31.63 & 9.09 & 22.54 & 1.40 \\
A5 & 31.64 & 9.15 & 22.67 & 1.41 \\
A6 & 32.56 & 9.89 & 22.48 & 1.44 \\
A7 & 32.84 & 10.36 & 24.06 & 1.46 \\
A8 & 33.27 & 9.21 & 22.46 & 1.38 \\
A9 & 33.71 & 11.25 & 21.94 & 1.50 \\
A10 & 33.77 & 11.83 & 22.38 & 1.54 \\
A11 & 33.90 & 11.52 & 23.39 & 1.51 \\
A12 & 34.11 & 10.72 & 26.32 & 1.46 \\
A13 & 34.14 & 7.82 & 25.26 & 1.30 \\
A14 & 34.25 & 8.99 & 22.43 & 1.34 \\
A15 & 34.68 & 12.25 & 22.39 & 1.55 \\
A16 & 34.94 & 13.40 & 26.48 & 1.62 \\
A17 & 34.98 & 12.59 & 25.83 & 1.56 \\
A18 & 35.32 & 8.84 & 25.46 & 1.33 \\
A19 & 35.70 & 9.87 & 25.61 & 1.38 \\
A20 & 36.34 & 10.88 & 28.34 & 1.43 \\
A21 & 36.97 & 11.36 & 8.71 & 1.44 \\
A22 & 37.05 & &
\end{tabular}


TABle 2: Continued.

\begin{tabular}{lcccc}
\hline IAHU & Built-up area $\left(\mathrm{m}^{2}\right)$ & Area occupied by common amenities and external walls & Carpet area $\left(\mathrm{m}^{2}\right)$ & Built-up area-to-carpet area ratio \\
\hline A23 & 37.31 & 12.02 & 25.29 & 1.48 \\
A24 & 39.20 & 13.30 & 25.90 & 1.51 \\
A25 & 40.52 & 10.53 & 29.99 & 1.35 \\
A26 & 40.76 & 11.83 & 28.93 & 1.41 \\
A27 & 40.80 & 11.37 & 29.43 & 1.39 \\
A28 & 40.82 & 12.04 & 28.78 & 1.42 \\
A29 & 41.58 & 13.18 & 28.40 & 1.46 \\
A30 & 42.06 & 14.73 & 27.33 & 1.54 \\
\hline
\end{tabular}

TABLE 3: Cost of common construction materials [50].

\begin{tabular}{lccccc}
\hline Items & Cement & Steel & Bricks & Sand & Coarse aggregate \\
\hline Unit & Bag of $50 \mathrm{~kg}$ & $\mathrm{~kg}$ & Per number & $\mathrm{m}^{3}$ & $\mathrm{~m}^{3}$ \\
\hline Cost in INR & 285.00 & 37.30 & 5.20 & 1200.00 & 1300.00 \\
\hline
\end{tabular}

TABLE 4: Embodied energies of construction materials [9, 46-48, 51].

\begin{tabular}{|c|c|c|c|c|}
\hline \multirow[b]{2}{*}{ S. no. } & \multirow[b]{2}{*}{ Item } & \multicolumn{2}{|c|}{ Embodied energy (MJ/kg) } & \multirow{2}{*}{$\begin{array}{c}\% \text { change in international to Indian scenario } \\
(\%)\end{array}$} \\
\hline & & Indian scenario & $\begin{array}{l}\text { International } \\
\text { source }\end{array}$ & \\
\hline 1 & Cement & $\begin{array}{c}5.9-7.8(\text { avg. } \\
6.85)\end{array}$ & 4.5 & -34 \\
\hline 2 & Fine aggregate & $0.1-0.2$ (avg. 0.15) & 0.83 & +453 \\
\hline 3 & Coarse aggregates & 0.4 & 0.83 & +107 \\
\hline 4 & Reinforcement steel & $\begin{array}{l}28.2-42 \text { (avg. } \\
35.1)\end{array}$ & 17.4 & -50 \\
\hline 5 & $\begin{array}{c}\text { Burnt clay bricks (weight of brick } 2.6 \mathrm{~kg} / \\
\text { no's) }\end{array}$ & 1.8 & 3 & +66 \\
\hline 6 & Lime wash & 5.65 & 5.3 & -6 \\
\hline 7 & Woodwork & 7.2 & 10 & +38 \\
\hline 8 & Copper wire & 110 & 36 & -67 \\
\hline 9 & PVC conduit & $\begin{array}{l}104-108 \text { (avg. } \\
106)\end{array}$ & 67.5 & -36 \\
\hline
\end{tabular}

TABLE 5: Built-up-to-carpet area ratio and construction cost for selected 30 IAHUs.

\begin{tabular}{lccc}
\hline IAHU & Built-up-to-carpet area ratio & Construction cost per unit carpet area (INR) & Construction cost per unit built-up area (INR) \\
\hline A1 & 1.42 & 16958.97 & 24113.59 \\
A2 & 1.47 & 16852.84 & 24723.98 \\
A3 & 1.34 & 17260.68 & 23091.69 \\
A4 & 1.40 & 17222.26 & 24167.70 \\
A5 & 1.41 & 17012.15 & 23933.49 \\
A6 & 1.44 & 16485.14 & 23676.94 \\
A7 & 1.46 & 16611.51 & 24267.00 \\
A8 & 1.38 & 15361.28 & 21241.48 \\
A9 & 1.50 & 17537.10 & 26321.27 \\
A10 & 1.54 & 19096.25 & 29392.91 \\
A11 & 1.51 & 20138.31 & 30504.41 \\
A12 & 1.46 & 16362.00 & 23860.97 \\
A13 & 1.30 & 15155.91 & 19658.34 \\
A14 & 1.36 & 14491.13 & 19648.50 \\
A15 & 1.55 & 18918.65 & 29250.95 \\
A16 & 1.62 & 18666.13 & 30278.30 \\
A17 & 1.56 & 19558.89 & 30559.67 \\
A18 & 1.33 & 15910.67 & 21222.24 \\
A19 & 1.38 & 17044.65 & 23557.65 \\
\hline
\end{tabular}


TABLE 5: Continued.

\begin{tabular}{lccc}
\hline IAHU & Built-up-to-carpet area ratio & Construction cost per unit carpet area (INR) & Construction cost per unit built-up area (INR) \\
\hline A20 & 1.43 & 16784.81 & 23957.58 \\
A21 & 1.44 & 16293.65 & 23521.14 \\
A22 & 1.31 & 13425.83 & 17552.11 \\
A23 & 1.48 & 15248.91 & 22496.51 \\
A24 & 1.51 & 18685.40 & 28270.77 \\
A25 & 1.35 & 14110.41 & 19064.82 \\
A26 & 1.41 & 15329.75 & 21598.36 \\
A27 & 1.39 & 16209.59 & 22472.01 \\
A28 & 1.42 & 15634.69 & 22175.40 \\
A29 & 1.46 & 16458.23 & 24096.25 \\
A30 & 1.54 & 18099.73 & 27854.91 \\
\hline
\end{tabular}

TABLE 6: Cost of major construction materials for selected 30 IAHUs in INR.

\begin{tabular}{|c|c|c|c|c|c|c|c|}
\hline IAHU & $\begin{array}{c}\text { Cement } \\
\text { a }\end{array}$ & $\begin{array}{c}\text { Steel } \\
\mathrm{b}\end{array}$ & $\begin{array}{l}\text { Bricks } \\
\text { c }\end{array}$ & $\begin{array}{l}\text { Sand } \\
\text { d }\end{array}$ & $\begin{array}{c}\text { Aggregate } \\
\mathrm{e}\end{array}$ & $\begin{array}{c}\text { Total cost } \\
a+b+c+d+e\end{array}$ & Percent of total cost of an IAHU \\
\hline A1 & 1499.1 & 1140.26 & 1980.83 & 681.6 & 494.77 & 5796.57 & 34 \\
\hline $\mathrm{A} 2$ & 1499.1 & 1147.72 & 2021.96 & 682.4 & 507.40 & 5858.59 & 35 \\
\hline A3 & 1556.1 & 1163.01 & 2272.6 .0 & 725.6 & 486.59 & 6203.92 & 36 \\
\hline A4 & 1556.1 & 1180.91 & 2202.72 & 716.8 & 501.45 & 6158.00 & 36 \\
\hline A5 & 1539.0 & 1176.81 & 2146.19 & 704.8 & 500.71 & 6067.53 & 36 \\
\hline A6 & 1487.7 & 1113.77 & 2030.28 & 680.8 & 499.22 & 5811.79 & 35 \\
\hline A7 & 1487.7 & 1117.88 & 2094.09 & 684.8 & 499.97 & 5884.44 & 35 \\
\hline A8 & 1390.8 & 1086.92 & 1856.29 & 628.0 & 470.25 & 5432.27 & 35 \\
\hline A9 & 1601.7 & 1217.84 & 2147.34 & 727.2 & 530.43 & 6224.52 & 35 \\
\hline A 10 & 1670.1 & 1228.28 & 2776.02 & 808.8 & 523.74 & 7006.95 & 37 \\
\hline A11 & 1812.6 & 1424.11 & 2785.84 & 846.4 & 563.86 & 7432.82 & 37 \\
\hline A12 & 1476.3 & 1099.6 & 2067.2 & 679.2 & 496.25 & 5818.57 & 36 \\
\hline A13 & 1402.2 & 1055.96 & 1847.92 & 632.8 & 458.36 & 5397.26 & 36 \\
\hline A14 & 1316.7 & 1042.53 & 1684.02 & 589.6 & 456.88 & 5089.74 & 35 \\
\hline A15 & 1664.4 & 1253.65 & 2682.26 & 796.0 & 526.71 & 6923.03 & 37 \\
\hline A16 & 1641.6 & 1253.65 & 2584.45 & 780.8 & 535.63 & 6796.14 & 36 \\
\hline A 17 & 1761.3 & 1396.51 & 2624.8 & 818.4 & 560.88 & 7161.91 & 37 \\
\hline A18 & 1459.2 & 1053.35 & 2077.08 & 675.2 & 473.22 & 5738.07 & 36 \\
\hline A19 & 1556.1 & 1134.66 & 2374.84 & 732.8 & 487.34 & 6285.75 & 37 \\
\hline A 20 & 1527.6 & 1146.97 & 2215.09 & 709.6 & 494.77 & 6094.04 & 36 \\
\hline A21 & 1493.4 & 1076.47 & 2160.49 & 693.6 & 491.05 & 5915.03 & 36 \\
\hline A22 & 1254.0 & 969.42 & 1481.01 & 548.8 & 443.51 & 4696.75 & 35 \\
\hline A23 & 1419.3 & 1062.67 & 1753.38 & 632 & 493.28 & 5360.65 & 35 \\
\hline A24 & 1704.3 & 1164.87 & 2800.51 & 824.8 & 523.74 & 7018.24 & 38 \\
\hline A 25 & 1328.1 & 980.61 & 1683.81 & 595.2 & 454.65 & 5042.38 & 36 \\
\hline A26 & 1413.6 & 1083.93 & 1964.09 & 646.4 & 475.45 & 5583.49 & 36 \\
\hline A 27 & 1527.6 & 1049.24 & 2245.82 & 713.6 & 484.37 & 6020.65 & 37 \\
\hline A28 & 1447.8 & 1021.64 & 2092.01 & 674.4 & 473.97 & 5709.83 & 37 \\
\hline A29 & 1533.3 & 1170.1 & 2187.06 & 704.0 & 506.65 & 6101.13 & 37 \\
\hline A30 & 1767.0 & 1211.5 & 2637.28 & 805.6 & 557.91 & 6979.31 & 39 \\
\hline
\end{tabular}

maximum ratio1.51 for IAHU, which is design no. A11. Design no. A17 with built-up area-to-carpet area ratio of 1.56 is very close to design no. A11.

Figure 4 makes it clear that design A22 is the most efficient design with cost of construction materials as INR 4,697 per $\mathrm{m}^{2}$, cost of construction INR 13,425 per $\mathrm{m}^{2}$ and embodied energy of $4.0 \mathrm{GJ}$ per $\mathrm{m}^{2}$ and design A11 (with built-up-to-carpet area ratio 1.51) is the most inefficient design with cost of construction materials as 7,433.00 per $\mathrm{m}^{2}$, construction cost as INR 20,138.00 per $\mathrm{m}^{2}$, and embodied energy as $6.5 \mathrm{GJ}$ per $\mathrm{m}^{2}$.
This study shows that the construction cost, cost of major construction materials, and EE are directly proportional to the built-up-to-carpet area ratio. The more the ratio, the more inefficient design would be. The cost of construction materials varies from INR 4,697.00 to 7,433.00 per $\mathrm{m}^{2}$ of carpet area, which is about $35 \%-37 \%$ of construction cost per sqm of carpet area. It is seen from this study that architectural designs have a major bearing on construction cost and embodied energy of the buildings; as in an architectural design, spaces are arranged in a particular way, which results in different placement of walls and 
TABLE 7: EE of major construction materials for selected 30 IAHUs in $\mathrm{MJ} / \mathrm{m}^{2}$ of the carpet area.

\begin{tabular}{|c|c|c|c|c|c|c|}
\hline IAHU & $\begin{array}{c}\text { Cement } \\
\text { a }\end{array}$ & $\begin{array}{c}\text { Steel } \\
\mathrm{b}\end{array}$ & $\begin{array}{l}\text { Bricks } \\
\text { c }\end{array}$ & $\begin{array}{c}\text { Sand } \\
\mathrm{d}\end{array}$ & $\begin{array}{c}\text { Aggregates } \\
\mathrm{e}\end{array}$ & $\begin{array}{c}\text { Total EE } \\
a+b+c+d+e\end{array}$ \\
\hline A1 & 1801.55 & 1073.01 & 1790.37 & 127.80 & 266.40 & 5059.13 \\
\hline A2 & 1801.55 & 1080.03 & 1827.55 & 127.95 & 273.20 & 5110.28 \\
\hline $\mathrm{A} 3$ & 1870.05 & 1094.42 & 2054.09 & 136.05 & 262.00 & 5416.61 \\
\hline $\mathrm{A} 4$ & 1870.05 & 1111.27 & 1990.92 & 134.40 & 270.00 & 5376.64 \\
\hline A5 & 1849.50 & 1107.41 & 1939.83 & 132.15 & 269.60 & 5298.49 \\
\hline A6 & 1787.85 & 1048.09 & 1835.07 & 127.65 & 268.80 & 5067.45 \\
\hline A7 & 1787.85 & 1051.95 & 1892.74 & 128.40 & 269.20 & 5130.13 \\
\hline A8 & 1671.40 & 1022.81 & 1677.81 & 117.75 & 253.20 & 4742.97 \\
\hline A9 & 1924.85 & 1146.02 & 1940.87 & 136.35 & 285.60 & 5433.68 \\
\hline A10 & 2007.05 & 1155.84 & 2509.10 & 151.65 & 282.00 & 6105.64 \\
\hline A11 & 2178.30 & 1340.12 & 2517.98 & 158.70 & 303.60 & 6498.70 \\
\hline A12 & 1774.15 & 1034.75 & 1868.44 & 127.35 & 267.20 & 5071.89 \\
\hline A13 & 1685.10 & 993.68 & 1670.24 & 118.65 & 246.80 & 4714.47 \\
\hline A14 & 1582.35 & 981.05 & 1522.10 & 110.55 & 246.00 & 4442.04 \\
\hline A15 & 2000.20 & 1179.71 & 2424.35 & 149.25 & 283.60 & 6037.12 \\
\hline A16 & 1972.80 & 1179.71 & 2335.95 & 146.40 & 288.40 & 5923.26 \\
\hline A17 & 2116.65 & 1314.14 & 2372.42 & 153.45 & 302.00 & 6258.66 \\
\hline A18 & 1753.60 & 991.22 & 1877.37 & 126.60 & 254.80 & 5003.59 \\
\hline A19 & 1870.05 & 1067.74 & 2146.49 & 137.40 & 262.40 & 5484.08 \\
\hline $\mathrm{A} 20$ & 1835.80 & 1079.33 & 2002.11 & 133.05 & 266.40 & 5316.68 \\
\hline A21 & 1794.70 & 1012.99 & 1952.76 & 130.05 & 264.40 & 5154.89 \\
\hline A 22 & 1507.00 & 912.25 & 1338.61 & 102.90 & 238.80 & 4099.56 \\
\hline A23 & 1705.65 & 1000.00 & 1584.79 & 118.50 & 265.60 & 4674.54 \\
\hline A24 & 2048.15 & 1096.17 & 2531.23 & 154.65 & 282.00 & 6112.21 \\
\hline A 25 & 1596.05 & 922.78 & 1521.91 & 111.60 & 244.80 & 4397.14 \\
\hline A26 & 1698.80 & 1020.01 & 1775.24 & 121.20 & 256.00 & 4871.24 \\
\hline A 27 & 1835.80 & 987.36 & 2029.88 & 133.80 & 260.80 & 5247.65 \\
\hline A28 & 1739.90 & 961.39 & 1890.86 & 126.45 & 255.20 & 4973.80 \\
\hline A29 & 1842.65 & 1101.09 & 1976.77 & 132.00 & 272.80 & 5325.31 \\
\hline A 30 & 2123.50 & 1140.05 & 2383.70 & 151.05 & 300.40 & 6098.70 \\
\hline
\end{tabular}

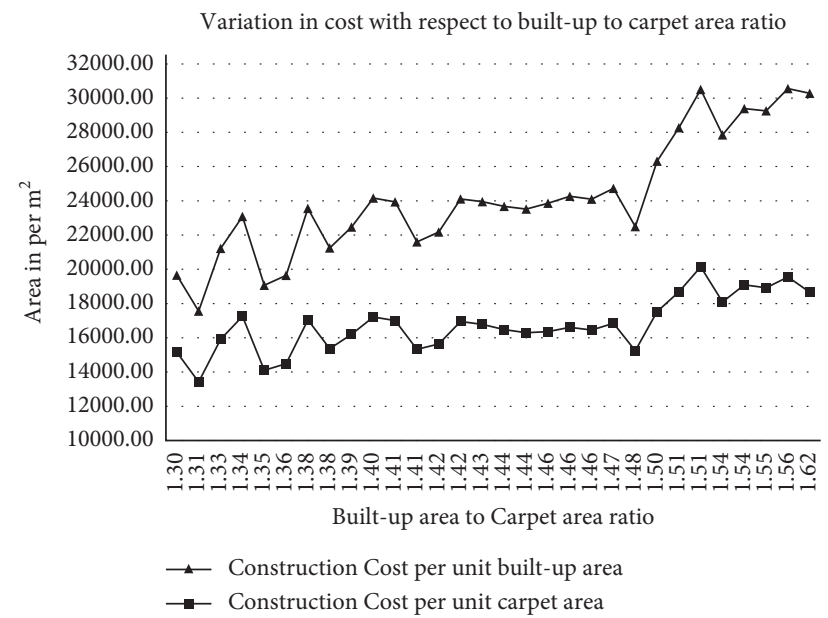

FIgURE 4: Variation in construction cost with respect to built-up-to-carpet area ratio. 
circulation areas. This results in different built-up areas for the same carpet areas in different architectural designs. To reduce the overall cost and $\mathrm{EE}$ of any building, its architectural design must be efficiently planned so that the builtup-to-carpet area ratio is at the minimum.

\section{Conclusion}

As per the norms of the Government of India, a carpet area of $30 \mathrm{~m}^{2}$ to $60 \mathrm{~m}^{2}$ is proposed for economically weaker sections and low-income groups. The total usable area (carpet area) per IAHU is calculated by subtracting the area consumed in the circulation spaces plus the area occupied by external walls from built-up areas. Increasing the area in common or circulation spaces reduces effective usable or carpet area per IAHU in a cluster, which increases consumption of construction materials. This results in an increase in construction cost and embodied energy of IAHUs. Thus, the built-up-to-carpet area ratio plays a major role in the sustainable and affordable design of IAHUs. This can be achieved by an efficient architectural design having more carpet area in a given built-up area, keeping the built-up-tocarpet area ratio minimum. The embodied energy of these houses is estimated as varying from 4 to $6.5 \mathrm{GJ} / \mathrm{sqm}$ of carpet area and with the built-up-to-carpet area ratio varying from 1.3 to 1.62 ; these values are $30 \%-62 \%$ higher on built-up area's basis, which is in line with embodied energy of lowrise Indian affordable houses $(1.6-5.0 \mathrm{GJ} / \mathrm{sqm})$ calculated by many researchers. This study is based on the analysis of 30 numbers of low-rise load-bearing designs of IAHUs of the most common typologies. In designing sustainable and affordable housing, it is essential to choose an efficient architectural design, which has the least variation in the ratio of the built-up and carpet area so that its CC and EE are minimized. Much information is available on construction materials about their cost and embodied energy, but very few researchers have worked on the efficiency of architectural design to design sustainable buildings. Efficient architectural designs are essential as $30 \%$ to $62 \%$ of the carpet area goes into external walls and circulation spaces, resulting in variation in embodied energy by $62.5 \%$ and construction cost by $50 \%$, which can be optimized in sustainable affordable housing. The built-up-to-carpet area ratio can give a true picture of the efficiency of affordable housing.

\section{Abbreviations}

Carpet area:

Load-bearing construction:

RCC:

RCC framed construction:

M25:
Floor area of a building within external walls

System of building construction, in which masonry/walls are the main load transferring members

Reinforced cement concrete System of building construction, in which RCC columns and beams are the main load transferring members Cement concrete, whose 28 days characteristic strength is $25 \mathrm{MPa}$ (Mega Pascal)
TMT:

Thermomechanically treated steel reinforcing bars

Plinth/built-up Carpet area plus floor area occupied by area: external walls along with proportional common/circulation areas including areas under lifts \& staircases

PMAY: $\quad$ Pradhan Mantri Awas Yojna (affordable housing scheme in India)

Indian affordable These are naturally ventilated houses houses: constructed with local construction materials for the poor, having about 20-30 $\mathrm{m}^{2}$ carpet area with two habitable rooms, one toilet \& bath and kitchen, bare minimum furnishings, with an average service life of about 50 years

EWS: $\quad$ Economically weaker section

EE: $\quad$ Embodied energy

OE: Operational energy

CC: Construction cost

IAHU: Indian affordable housing units

LCA/LCEA: $\quad$ Life cycle analysis/life cycle energy analysis

1 USD (\$): $\quad 73$ INR as in May 2021.

\section{Data Availability}

All the data used in this work are available from the corresponding author upon reasonable request.

\section{Conflicts of Interest}

The authors declare that they have no conflicts of interest.

\section{Acknowledgments}

The authors are thankful for and acknowledge the support and help provided by Mrs. Manju Safaya, Ex. Executive Director (Design), HUDCO, New Delhi, India, for providing permission to use the housing data of the HUDCO for carrying out this research. The authors are also thankful to Dr Shailesh Kr. Agarwal, Executive Director, Building Materials and Technology Promotion Council (BMTPC), New Delhi, India, and Ms Yashika Bansal, student of B. Design, FDDI, Noida, India, for constant encouragement and help in analyzing data and for critical comments during this study.

\section{References}

[1] Ipcc, Working Group III Contribution to the Fourth Assessment, Report of the IPCC [AR4], 2007.

[2] T. Ramesh, R. Prakash, and K. Kumar Shukla, "Life cycle energy analysis of a multifamily residential house: a case study in indian context," Open Journal of Energy Efficiency, vol. 2, no. 1, pp. 34-41, 2013.

[3] L. Pinky Devi and S. Palaniappan, "Life cycle energy analysis of a low-cost house in India," International Journal of Construction Education and Research, vol. 15, no. 4, pp. 256-275, 2018. 
[4] J. S. Paulsen and R. M. Sposto, "A life cycle energy analysis of social housing in Brazil: case study for the program "my house my life"," Energy and Buildings, vol. 57, pp. 95-102, 2013.

[5] I. C. Ezema, A. O. Olotuah., and O. I. Fagbenle, "Estimating embodied energy in residential buildings in a Nigerian context," International Journal of Applied Engineering Research, vol. 10, no. 24, pp. 44140-44149, 2015.

[6] R. Barbara, M. Anne-Françoise, G. Mauritz, and R. Sigrid, "Life-cycle assessment of residential buildings in three different European building and environment," Building and Environment, vol. 51, pp. 395-401, 2012.

[7] D. Bansal, R. Singh, and R. L. Sawhney, "Effect of construction materials on embodied energy and cost of buildings-a case study of residential houses in India up to $60 \mathrm{~m} 2$ of plinth area," Energy and Buildings, vol. 69, pp. 260-266, 2014.

[8] M. K. Dixit, J. L. Fernández-Solís, S. Lavy, and C. H. Culp, "Need for an embodied energy measurement protocol for buildings: a review paper," Renewable and Sustainable Energy Reviews, vol. 16, no. 6, pp. 3730-3743, 2012.

[9] L. Pinky Devi and S. Palaniappan, "A case study on life cycle energy use of residential building in Southern India," Energy and Buildings, vol. 80, pp. 247-259, 2014.

[10] C. K. Chau, T. M. Leung, and W. Y. Ng, "A review on life cycle assessment, life cycle energy assessment and life cycle carbon emissions assessment on buildings," Applied Energy, vol. 143, pp. 395-413, 2015.

[11] P. Crowther, "Design for disassembly to recover embodied energy," in Proceedings of the 16th International Conference on Passive and Low Energy Architecture, S. S. Szokolay, Ed., pp. 22-24, Melbourne, Brisbane, Cairns, September 1999.

[12] N. Sengupta, S. Roy, and H. Guha, "Assessing embodied GHG emission reduction potential of cost-effective technologies for construction of residential buildings of Economically Weaker Section in India," Asian Journal of Civil Engineering, vol. 19, no. 2, pp. 139-156, 2018.

[13] T. Ramesh, R. Prakash, and K. K. Shukla, "Life cycle energy analysis of buildings: an overview," Energy and Buildings, vol. 42, no. 10, pp. 1592-1600, 2010.

[14] P. Winistorfer, Z. Chen, B. Lippke, and N. Stevens, "Energy consumption and greenhouse gas emissions related to the use, maintenance, and disposal of a residential structure," Wood and Fiber Science, vol. 37, no. 2007, pp. 128-139, 2007.

[15] W. David, E. Lucia, W. Russel, and F. Chris, "Climate change influence on building lifecycle greenhouse gas emissions: case study of a UK mixed-use development," Energy and Buildings, vol. 48, pp. 112-126, 2012.

[16] T. Y. Chen, J. Burnett, and C. K. Chau, "Analysis of embodied energy use in the residential building of Hong Kong," Energy, vol. 26, no. 4, pp. 323-340, 2001.

[17] A. Stephan, R. H. Crawford, and K. de Myttenaereb, “A comprehensive assessment of the life cycle energy demand of passive houses," Applied Energy, vol. 112, pp. 23-34, 2013.

[18] A. Utama and S. H. Gheewala, "Life cycle energy of single landed houses in Indonesia," Energy and Buildings, vol. 40, no. 10, pp. 1911-1916, 2008.

[19] A. Debnath, S. V. Singh., and Y. P. Singh, "Comparative assessment of energy requirements for different types of residential buildings in India," Energy and Buildings, vol. 23, no. 2, pp. 141-146, 1995.

[20] D. Bansal, V. K. Minocha, and K. Arvinder, "Embodied energy, $\mathrm{CO}_{2} \mathrm{e}$, and construction cost of indian housing: model of low-rise versus high-rise development," Journal of Architectural Engineering, vol. 27, no. 3, 2021.
[21] L. Gustavsson and A. Joelsson, "Life cycle primary energy analysis of residential buildings," Energy and Buildings, vol. 42, no. 2, pp. 210-220, 2010.

[22] U. Y. A. Tettey, A. Dodoo, and L. Gustavsson, "Effects of different insulation materials on primary energy and $\mathrm{CO}_{2}$ emission of a multi-storey residential building," Energy and Buildings, vol. 82, pp. 369-377, 2014.

[23] X. G. Casals, "Analysis of building energy regulation and certification in Europe: their role, limitations and differences," Energy and Buildings, vol. 38, no. 5, pp. 381-392, 2006.

[24] A. Z.-Z. Szalay, "What is missing from the concept of the new European building directive?" Building and Environment, vol. 42, no. 4, pp. 1761-1769, 2007.

[25] S. S. Shrestha, K. Biswas, and A. O. Desjarlais, "A protocol for lifetime energy and environmental impact assessment of building insulation materials," Environmental Impact Assessment Review, vol. 46, pp. 25-31, 2014.

[26] F. Luisa, B. Camila, M. Josep, B. Esther, and A. Inés Fernández, "Low carbon and low embodied energy materials in buildings: a review," Renewable and Sustainable Energy Reviews, vol. 23, pp. 536-542, 2013.

[27] F. H. Abanda and J. H. M. Tah, F. K. T. Cheung, "Mathematical modelling of embodied energy, greenhouse gases, waste, time-cost parameters of building projects: a review," Building and Environment, vol. 59, pp. 23-37, 2013.

[28] A. Dodoo, L. Gustavsson, and R. Sathre, "Building energyefficiency standards in a life cycle primary energy perspective," Energy and Buildings, vol. 43, no. 7, pp. 1589-1597, 2011.

[29] G. A. Keoleian, S. Blanchard, and P. Reppe, "Life-cycle energy, costs, and strategies for improving a single-family house," Journal of Industrial Ecology, vol. 4, no. 2, pp. 135-156, 2000.

[30] Ministry of Housing \& Urban Affairs, Affordable Housing, http://mohua.gov.in/w_new/AffordableHousing.pdf accessed on 2-March-2019, 2019.

[31] D. Bansal, V. K. Minocha, and A. Kaur, "Componentwiseembodied energy analysis of affordable houses in India," Asian Journal of Civil Engineering, vol. 21, no. 1, pp. 137-145, 2020.

[32] D. Sutapa, "Analysis of energy saving potential of a residential building complex using energy conservation building code 2017," in Proceedings of the annual International conference on Architecture and Civil Engineering (ACE 2018), pp. 23-31, Singapore, May 2018.

[33] J. Oyarzo and B. Peuportier, "Life cycle assessment model applied to housing in Chile," Journal of Cleaner Production, vol. 69, pp. 109-116, 2014.

[34] P. K. Das, "Planning and design for sustainable habitat: adoption of appropriate and green construction technologiesthe need of the day," in Proceedings of the National Seminar on Design \& Planning for Sustainable Habitat, IDRC,CRDI, HSMI HUDCO, Background Papers, New Delhi, July 2011.

[35] F. Pomponi, C. De Wolf, and A. Moncaster, Embodied Carbon in Buildings: Measurement, Management, and Mitigation, Springer Science, New York, NY, USA, 2018.

[36] European Standard 15978, Sustainability of Construction Works -ASSESSMENT of Environmental Performance of Buildings - Calculation Method, p. 66, European Committee for Standardization (CEN), Brussels, Belgium, 2011.

[37] M. K. Dixit, "Life cycle embodied energy analysis of residential buildings: a review of literature to investigate embodied energy parameters," Renewable and Sustainable Energy Reviews, vol. 79, pp. 390-413, 2017.

[38] A. Stephan and R. H. Crawford, "The relationship between house size and life cycle energy demand: implications for 
energy efficiency regulations for buildings," Energy, vol. 116, no. 1, pp. 1158-1171, 2016.

[39] R. Pacheco-Torres, E. Jadraque, J. Roldán-Fontana, and J. Ordóñez, "Analysis of $\mathrm{CO}_{2}$ emissions in the construction phase of single-family detached houses," Sustainable Cities and Society, vol. 12, pp. 63-68, 2014.

[40] A. Stephan and A. Athanassiadis, "Quantifying and mapping embodied environmental requirements of urban building stocks," Building and Environment, vol. 114, pp. 187-202, 2017.

[41] L. Antonín, N. Marie, M. Štěpán et al., "Design strategies for buildings with low embodied energy," Proceedings of the Institution of Civil Engineers - Engineering Sustainability, vol. 170, no. 2, pp. 65-80, 2017.

[42] L. Vukotic, R. A. Fenner, and K. Symons, "Assessing embodied energy of building structural elements," Proceedings of the Institution of Civil Engineers - Engineering Sustainability, vol. 163 , no. 3, pp. 147-158, 2010.

[43] Z. Worth, C. Boyle, and W. R. McDowall, "Combined lifecycle cost assessment of roof construction," Proceedings of the Institution of Civil Engineers - Engineering Sustainability, vol. 160, no. 4, pp. 189-198, 2007.

[44] B. Deepak and V. K. Minocha, "Analysis of low-rise vs. high rise development of affordable housing in India, for cost and energy optimization," in Proceedings of the International Conference on Clean Technologies and Sustainable Development, pp. 105-111, NITTTR Chandigarh and DOST, GOI, Chandigarh, February 2018.

[45] National Building Code 2016, "Bureau of Indian standards," 2016, http://www.bis.org.in/sf/nbc.html -accessed on 2March-2015.

[46] A. B. Saka and D. W. M. Chan, "Knowledge, skills and functionalities requirements for quantity surveyors in building information modelling (BIM) work environment: an international Delphi study," Architectural Engineering and Design Management, vol. 16, no. 3, pp. 227-246, 2019.

[47] A. F. Mohamed, M. Mokhtar, and S. Elghobashy, "Comparative study of bio-materials versus conventional materials in building construction methods; economical evaluation of different building materials," SN Applied Sciences, vol. 1, no. 10, 2019.

[48] B. Borah, V. Singhal, and H. B. Kaushik, "Sustainable housing using confined masonry buildings," SN Applied Sciences, vol. 1, no. 9, 2019.

[49] Development Alternatives (Da), Energy Directory of Building Materials, Building Materials \& Technology Promotion Council, New Delhi, India, 1995.

[50] Bmtpc (Building Materials and Technology Promotion council, New Delhi, http://www.bmtpc.org.

[51] V. A. Dakwale, R. V. Ralegaonkar, and S. Mandavgane, "Improving environmental performance of building through increased energy efficiency: a review," Sustainable Cities and Society, vol. 1, no. 4, pp. 211-218, 2011.

[52] B. V. Venkatarama Reddy and K. S. Jagadish, "Embodied energy of common and alternative building materials and technologies," Energy and Buildings, vol. 35, no. 2, pp. 129-137, 2003.

[53] A. Shukla, G. N. Tiwari., and M. S. Sodha, "Embodied energy analysis of adobe house," Renewable Energy, vol. 34, no. 3, pp. 755-761, 2009.

[54] Inventory of Carbon \& Energy, University of Bath, 2011, http://www.bath.ac.uk/mech-engg/sert/embodied.
[55] Central Public Works Department (Cpwd 2019), Plinth Rates, https://cpwd.gov.in/Publication/PLINTH_AREA_RATES_ 2019.pdf -accessed on 5-November-2020. 